\title{
El auto sacramental de El caballero de Gracia (BNE/mss. 16568): cruzada espiritual sobre las tablas
}

\author{
The «Auto Sacramental» El caballero de Gracia \\ (BNE/mss. 16568): A Spiritual Crusade on the Stage
}

\author{
Rafael Massanet Rodríguez \\ Universitat de les Illes Balears - Instituto de Estudios Hispánicos en la Modernidad \\ r.massanet.r@gmail.com \\ ORCID iD: https://orcid.org/0000-0001-9340-1708
}

\section{RESUMEN}

El auto sacramental de El caballero de Gracia es una obra que se ve influenciada por toda la situación cultural, social e historia de su época. De autor desconocido, se trata de un texto profundamente antiluterano que pretende difundir los dogmas de la fe católica entre los espectadores al tiempo que batalla contra las ideas reformistas que empezaban a difundirse entre la población. Para ello, insiste en retratar las herejías del lado del demonio y reforzar el dogma de fe a través de los personajes y alegorías de los pasajes más representativos del Nuevo y Antiguo Testamento. La escena se convierte en un púlpito sobre el que los actores predican la palabra sagrada y la hacen asequible para el espectador de la época.

Palabras Clave: El caballero de Gracia; auto sacramental; contrarreforma; Lutero; Tirso de Molina; Alonso Remón.

\section{ABSTRACT}

The allegorical religious play El caballero de Gracia is influenced by the entire cultural, social, and historical situation of its time. Written by an unknown author, it is a profoundly anti-Lutheran text that seeks to spread the dogmas of the Catholic faith among the audience while fighting against the reformist ideas that were beginning to spread among the population. For this reason, the author insists on portraying the heresies on the devil's camp and reinforcing the dogma of faith through the characters and allegories of the most representative passages of the New and Old Testaments. The stage becomes a pulpit on which the actors preach the sacred word and make it accessible to the spectators of the time.

Key words: El caballero de Gracia; Allegorical religious play; Counter reformation; Lutero; Tirso de Molina; Alonso Remón. 


\section{ESTADO DE LA CUESTIÓN}

El documento con la signatura Ms/16568 que está localizado en la Biblioteca Nacional de España contiene el manuscrito que lleva por título: El Caballero de Gracia [manuscrito]: auto sacramental. Según los datos del catálogo, procede de la biblioteca del duque de Osuna y consta de diecisiete folios de veintiún centímetros de alto por dieciséis de ancho. La escritura es clara y constante, lo que nos indica un único copista. No obstante, a lo largo de su redacción encontramos fragmentos tachados, correcciones de palabras, anotaciones al margen que añaden y corrigen versos. Todo ello parece indicar que este manuscrito fue utilizado para la representación. No aparece el nombre de su autor o alguna referencia que pudiera servir para identificarlo, por lo que puede tratarse de una copia, ya fuere de otra o del original, y usada por un actor o compañía para representarla. Esta hipótesis se sustenta también por el escaso número de acotaciones que aparecen indicadas, en las que escuetamente se mencionan las entradas o salidas del escenario. E incluso así, muchas de ellas son incorrectas, pues aparecen personajes sin aviso previo o acontecimientos destacados que surgen de la interacción entre dos o más personajes, los cuales no son mencionados. Todo ello condiciona a quien quiera acercarse al texto, pues deberá reconstruir por contexto estas acciones no explícitas. Sin duda, son aspectos que quien tuviera una copia debía de conocer con anterioridad para poder llevar a cabo la representación.

Actualmente no existe ningún estudio que preste atención a este auto sacramental. No obstante, no significa que no se puedan localizar noticias sobre su presencia entre la crítica, pues lo encontramos mencionado o referenciado en algunos estudios y catálogos atribuyéndolo al repertorio dramático de algún autor, aunque sin aportar prueba alguna. Entre los más repetidos destacan Tirso de Molina y Alonso Remón, al contar entre su repertorio literario obras con este título, dedicadas a la figura de Jacobo de Grattis, conocido en su época como el Caballero de Gracia. Remón, por su parte, escribió una obra en prosa titulada Vida ejemplar y muerte del Caballero de Gracia (1620), en la cual Tirso se basaría a la hora de elaborar su comedia. No obstante, estos textos no tienen nada que ver con este auto sacramental. El único paralelismo que se establece es a través de la similitud en el título, siendo este, posiblemente, el motivo por el que la crítica ha presentado una tendencia en atribuírsela a Tirso de Molina. Rodríguez Puértolas señala, además, al Fénix de los ingenios como posible candidato: «El caballero de Gracia, auto cuya paternidad se atribuye indistintamente a Lope y a Tirso de Molina» $(1970,98)$. Alenda y Mira, por su parte, lo atribuye de manera directa al autor mercedario: «CABALLERO (EL) DE GRACIA.- Auto sacramental de fray Gabriel Téllez. Citan Durán y La Barrera la comedia de este título de Tirso; pero no el Auto, que sólo aparece como anónimo en el Catálogo del segundo» (2010). Además aporta una signatura del documento incorrecta, Mss. 16.569. La Barrera, tal como se encarga 
de señalar Alenda y Mira, lo considera de autor anónimo. Ven Serna, entre otros, se lo atribuye a Alonso Remón, dramaturgo mercedario, aunque con un detalle relevante que demuestra que ha tenido acceso al texto, pues especifica su contenido: «sobre Cristo y no acerca de Jacobo Trenzi como creía doña Blanca» (1967, 594).

Como podemos comprobar, la autoría de esta pieza no está nada clara. Los motivos que argumentan para atribuírselo tanto a Tirso de Molina como a Remón, cuando los hay, son simplemente circunstanciales. Un análisis detallado de la obra desmonta las afirmaciones expresadas anteriormente. Respecto al estilo de Téllez, podemos señalar que este auto no comparte la riqueza léxica que caracterizaba a este autor: la construcción de la acción es torpe e irregular y la métrica se aleja bastante de la que el dramaturgo usó en otros autos propios $^{1}$. Nos es imposible, a día de hoy, afirmar con total seguridad quién es el verdadero autor de esta obra, por lo que optamos por mantenerlo anónimo, tal como señala La Barrera en su Catálogo. La atribución de esta obra a ciertos autores basándonos en que tienen en su haber otras de título similar, sin dar mayores razones, no es motivo suficiente.

En cuanto a su datación, es complicado poder llegar a unas conclusiones definidas debido a la falta de información que aporta el propio manuscrito y contradicciones respecto a las noticias que se tienen de su representación en relaciones o avisos de la época. En el Expediente de las fiestas del Corpus de Madrid publicado en 1614 se da noticia de una representación de un auto sacramental que lleva este título: «El jueves por la tarde harán la primera representación todos cuatro autos a Su Majestad, empezando [...] Y luego Morales, con el de El Caballero de Gracia» (Expediente de las fiestas del Corpus de Madrid, 1614.- Archivo de la villa, 2a , 272, 17. Citamos a partir de Alenda y Mira, 2010). No obstante, en el propio manuscrito se menciona hacia el final a Felipe IV como monarca regente en el momento de la representación o escritura:

\footnotetext{
Pues que soy la Fe de España

y la Inquisición me anima, que fundó el rey don Fernando contra la misma Malicia.

Aquí en don Felipe Cuarto

de tal suerte resucita

que para mí solo forma

el palacio donde habita (f. 17)
}

\footnotetext{
${ }^{1}$ Morley (1914) se ha encargado del análisis de las combinaciones métricas de la obra de Tirso de Molina. Así mismo, cabe destacar el exhaustivo trabajo de Fernández (1991) en cuanto a la métrica de toda su obra.
} 
Esta referencia sitúa al texto entre 1621 y 1665 , período demasiado amplio y que, además, entra en contradicción con la noticia de representación que hemos señalado. A esta razón surgen dos hipótesis. La primera es que el auto original sí se representara en 1614 en las fiestas del Corpus de Madrid y que, posteriormente, el texto fuera modificado por la compañía que lo adquiriera para nuevas representaciones. La segunda es que se tratara de otro auto sacramental con el mismo título, de autor anónimo. Hemos podido localizar un ejemplar, perteneciente a una colección privada, pero que en 1952 Joaquín de Entrambasguas publicó en edición facsímil con un breve estudio introductorio. No obstante, se trata de una edición de muy mala calidad en la que el texto manuscrito presenta grandes dificultades para su lectura. Aunque ambas piezas comparten título, se trata de textos diferentes.

\section{Historia DE UNA BATALLA ETERNA}

El relato que se narra en este auto sacramental se centra en torno a la batalla entre los ejércitos del Bien y del Mal, los cuales se disputan el alma del Hombre. Se desarrolla el motivo bíblico de su caída en el pecado como consecuencia de la tentación diabólica que, según el texto sagrado, determina la muerte sin posibilidad de salvación. El conflicto de la pieza, por tanto, orbita en torno a dos puntos: la caída en el pecado y la redención, en forma de aversio y conversio. Hay que tener en cuenta que el hombre es libre, en todo momento, de tomar un camino u otro e incluso de regresar.

La acción comienza con el Hombre, junto a Honor y Cuidado, vanagloriándose de sus virtudes y posesiones materiales. Sus acompañantes intentan advertirle sobre su soberbia actitud y los peligros que le puede acarrear. No obstante, desoye sus consejos y pronto aparece en escena Malicia, bajo el disfraz de Ignorancia. Mediante ardides y engaños bien planeados, consigue doblegar la voluntad del Hombre gracias a Lisonja. Cuidado y Honor no tardan en abandonarlo, dejándolo a su suerte. Finalmente, Malicia arrastra al Hombre al pecado, condenando su alma a Luzbel. Aparece entonces san Juan Bautista en su faceta de profeta de la llegada del Mesías, anunciando a Malicia, y a los espectadores, los hechos que ocurrirán a continuación: el caballero de Gracia está de camino para salvar las almas de los hombres del pecado y redimirlas. Para ello combatirá contra el general de las fuerzas del Mal. No obstante, toda esta declaración es ignorada por el Hombre. Tras la marcha de san Juan, la Muerte se aparece ante él. Entonces es consciente de que ha pecado y se ha alejado de la senda del Bien. Malicia se quita el disfraz, descubriendo su verdadera naturaleza y lo conduce ante su señor, quien manda encerrar al Hombre. Mediante un diálogo con Envidia, narra todo el Apocalipsis y el Génesis, ofreciendo uno de los primeros y extensos sermones bíblicos del auto sacramental. Pero su relato se ve interrumpido por la llegada de las naves del Ca- 
ballero de Gracia y sus ejércitos. Ante la invasión de su reino, Luzbel arma a sus tropas, rodeándose de los enemigos de la Iglesia, vicios, pecados y herejes. Entra en escena la nave del caballero de Gracia, ricamente engalanada y acompañado de sus apóstoles, la Fe y la Iglesia, bajo el nombre de la Esposa. El Caballero, entonces, predica ante sus tropas un sermón en el que explica su propia vida, pues es Cristo, y junto con la Fe, expone de forma clara los principios del dogma católico.

Una vez llegado a puerto, comienza la batalla y ambos ejércitos toman posiciones. Luzbel pretende impresionar al ejército rival con el despliegue de la totalidad de sus fuerzas, pero la contienda se acabará resolviendo en duelo singular, con la Fe como mantenedora del Caballero y Malicia de Luzbel. Se aproximan ambas figuras bien armadas, acompañadas de sus testigos y comienza la batalla, no tan solo física, sino también dialéctica, pues se tiene que demostrar con palabras la superioridad del pensamiento católico frente a los males que le acechan. Finalmente, la Fe se alza vencedora frente a la Malicia y la Herejía. Sin embargo, la batalla no está ganada, pues Amor, que ha aparecido junto al Hombre y el Mundo al inicio del duelo, atraviesa con una lanza el cuerpo del Caballero. Es ahora cuando se produce la verdadera derrota del ejército del Mal, pues Cristo, mediante su sacrificio por Amor al Hombre, consigue redimirlo y otorgarle la salvación. Su sacrificio, por tanto, se contempla como el acto supremo de entrega. Luzbel y sus tropas huyen, no sin antes prometer su regreso. El Caballero perdona al Hombre por sus pecados y lo acoge de nuevo en su seno.

El auto sacramental acaba con una gran fiesta, risas, regocijo y bailes, festejando la salvación del Hombre y la victoria de Cristo frente al Mal.

\section{LOS DOS EJÉRCITOS}

El listado de dramatis personae de este auto sacramental refiere catorce personajes, aunque a lo largo del texto llegan a aparecer mencionados hasta treinta y cuatro. Podemos establecer una diferenciación entre personajes actuantes y personajes figurativos, pues muchos no tienen diálogo y tan solo aparecen en momentos puntuales, como miembros de una comparsa, para volver a desaparecer a continuación.

En total tenemos dieciocho personajes actuantes: el Caballero de Gracia, el Hombre, Cuidado, Honor, Tiempo, Mundo, la Fe, san Pedro, santo Domingo, san Juan Bautista, Amor, Luzbel, Herejía, Malicia, Envidia, Lisonja, Voluntad y la Muerte. Estos personajes tienen presencia y diálogo en escena. Frente a ellos, encontramos quince personajes figurativos: san Francisco de Asís, san Agustín, santo Tomás, san Pablo, san Juan Evangelista, la Esposa, Arrio, Martín Lutero, Nerón, Pompeyo, Rómulo, Trajano, Atila, Diocleciano Maximiliano y Calvino. Debido a las escasas acotaciones de este manuscrito, en muchas 
ocasiones no se señala la entrada y salida de este tipo de personajes y somos conscientes de su presencia a través de los diálogos. Su función es la de reforzar el discurso y las posiciones morales y religiosas de los actuantes.

Además de esta primera división centrada en su función escénica, podemos separar a los personajes en hasta tres grupos, dependiendo del bando al que pertenezcan, pues, en conjunto, son tropas de uno de los dos ejércitos que se enfrentan por la salvación o condenación del alma del Hombre, quien desempeña un papel neutral: «Entre el Bien y el Mal, Dios y el Demonio, y sus respectivos agentes y servidores, se encuentra el Hombre, sometido a la Muerte, que sufre en sí mismo el conflicto entre cuerpo y alma, apetitos y razón, inclinaciones concupiscentes y libre albedrío» (Arellano 2001 208).

El Hombre representa en este auto sacramental a todos los de su especie y, como tal, ofrece una lección universal: «dramatiza un proceso de caída y redención en que el hombre, situado entre las asechanzas del demonio y la gracia de Dios, es el protagonista de su propia historia, libre $-\mathrm{y}$ por tanto responsable - para desarrollar su proyecto vital» (Arellano 2001, 7). Este personaje carece de nombre propio, por lo que se convierte en una entidad cuya finalidad es la de identificación con el espectador, el elemento de conexión con la realidad en una obra de contenido alegórico. El Hombre representa en este auto a todos los de su especie y, por tanto, ofrece una lección universal.

Lo único que conocemos de este personaje al inicio del auto es que se trata de un soldado que se ha separado de su tropa. Este oficio no es casual, pues el autor juega con el doble concepto de 'soldado', como aquel que es miembro de un ejército y como cristiano, tal como recoge el Diccionario de Autoridades: «Metafóricamente se dice del cristiano, porque por el bautismo entra en la Iglesia militante y como que sienta plaza debajo de las banderas de Cristo». Presenta, por tanto, bajo esta figura el tópico, fundamentalmente paulino, del miles christi, el soldado cristiano que se enfrenta contra las fuerzas del Mal, personificadas en la figura de Luzbel y las herejías. En la Biblia ya aparece referido este motivo, tanto en el Antiguo como en el Nuevo Testamento:

¿Acaso no es una milicia lo que tiene el hombre en la tierra? ¿No son sus días como los días de un asalariado? (Job 7,1).

Por lo demás, hermanos míos, fortaleceos en el Señor, y en el poder de su fuerza. Vestíos de toda la armadura de Dios, para que podáis estar firmes contra las asechanzas del diablo. Porque no tenemos lucha contra sangre y carne, sino contra principados, contra potestades, contra los gobernadores de las tinieblas de este siglo, contra huestes espirituales de maldad en las regiones celestes. Por tanto, tomad toda la armadura de Dios, para que podáis resistir en el día malo, y habiendo acabado todo, estar firmes. Estad, pues, firmes, ceñidos vuestros lomos con la verdad, y vestidos con la coraza de justicia, y calzados los pies con el apresto del evangelio de la paz. Sobre todo, tomad el escudo de la fe, con que podáis apagar todos los dardos de fuego del maligno. Y tomad el yelmo de la salvación, y la espada del Espíritu, que es la palabra de Dios; orando en todo tiempo con toda 
oración y súplica en el Espíritu, y velando en ello con toda perseverancia y súplica por todos los santos (Efesios 6,10-18).

Tú, pues, sufre penalidades como buen soldado de Jesucristo (2 Timoteo 2, 3).

Pero nosotros, que somos del día, seamos sobrios, habiéndonos vestido con la coraza de fe y de amor, y con la esperanza de salvación como yelmo (1 Tesalonicenses 5,8$)$.

Herrán Alonso ofrece una panorámica de la evolución de este tópico en la que analiza su aparición a lo largo de la literatura y religión durante el Medievo y el Renacimiento. Así señala al alejandrino Orígenes como el más destacado entre los Padres de la Iglesia precursores que contribuyeron a su configuración:

Identifica la vida del cristiano como un combate espiritual perpetuo, no solo entendido como lucha del espíritu contra la carne, sino interpretada también como un combate de dimensiones cósmicas entre los mundos angélico, diabólico y terrenal. El monacato primitivo hace suyas estas ideas hasta el punto de identificar como equivalentes la expresión «miles chirsti» y monje, proliferando en sus escritos expresiones del tipo «militar de Cristo», «milicia espiritual», «milicia de Cristo» o «milicia celeste» para referirse a la vida monástica: san Jerónimo identifica hacerse monje con «correr en el campo de batalla»; san Juan Crisóstomo destaca la grandeza del combate de los monjes; Casiano identifica la vida monástica con una lucha; san Pacomio se refiere al «combate del monacato» $(2005,880)$.

Por tanto, la idea de cruzada que se trasluce también en el auto parte de la vinculación que se establece desde el seno de la Iglesia:

En el 1095, el Papa Urbano II invita al cristiano a «abandonar la milicia del siglo», la caballería (s. XI), «para entrar en la de Cristo, no como monje, sino como guerrero» y así entrar a formar parte del ejército de Dios que el Papa lanza hacia Jerusalén para liberar el santo sepulcro, en manos de los infieles desde el año 638. A los que partan sin intención de ganancias materiales, sino con un espíritu de piedad, el Papa les ofrece la anulación de sus penitencias y la plena remisión de sus pecados. La primera cruzada nacía, entonces, como una peregrinación, como una guerra santa y necesaria, al tiempo que como una penitencia satisfactoria $(2005,881)$.

El tópico se perpetuará durante el siglo XVI gracias también al Enchiridion militiis christiani (1501) de Erasmo de Rotterdam, así como en los múltiples libros de caballerías «a lo divino» que se escriben durante la segunda mitad del siglo. La fuente principal de estos será la versión de Le chevalier délibéré de Olivier de la Marche, traducido al español por el poeta Hernando de Acuña bajo el título El caballero determinado en 1553. Este libro supone un paradigma para la composición de obras posteriores de motivo similar gracias, sobre todo, al beneplácito de Carlos V. Acuña dedica su traducción al monarca, quien siente gran predilección por el espíritu moral y, además, se ve reflejado como rey cristiano: 


\begin{abstract}
Al margen del trajín actual y real de la política, Carlos debía comprender la vida tal como esos libros, tal como Le chevalier délibéré, la representaban abstractamente, tejiendo alegorías en torno a la aventura del hombre sobre la tierra y al juego y lucha de vicios, tentaciones y virtudes que va a decidir de su salvación (Clavería 1950, 93).
\end{abstract}

El miles christi evoluciona, por tanto, desde el monje al caballero, desde las armas metafóricas hasta toda la panoplia que acabará vistiendo. Y todo ello lo acabamos encontrando en este auto sacramental: la idea de cruzada como liberación del alma a través de la fuerza pero, sobre todo, a través de la Fe. Bajo una caracterización militarizada, los ejercicios espirituales y la devoción católica se convierten en las verdaderas armas con las que enfrentarse a la herejía como, por otra parte, será común, por lo que al léxico militar se refiere, en el género de la predicación sagrada.

Además, este Hombre tiene libre albedrío en sus decisiones, potestad que Lutero rechaza, dada su apuesta por el determinismo, en su obra De servo arbitrio, respuesta a De libero arbitrio de Erasmo. Según la Iglesia católica, el hombre puede libremente aceptar o rechazar la gracia que Dios le ofrece para salvarse. Así, este personaje, se aleja al comienzo del auto sacramental por su propio pie del cuerpo del ejército del Caballero. Piensa que las virtudes del mundo son suyas para disfrutarlas y acaba engañado y en manos de los vicios y los pecados como la Envidia, la Malicia, la Lisonja, etc., por mucho que sus compañeros Cuidado y Honor intenten advertirle. Es él mismo quien, al ignorar lo que le aconsejan, acaba cayendo en desgracia y se convierte en prisionero de Luzbel. Sirve este personaje, por tanto, para mostrar como el alejarse del recto camino puede condicionar su perdición. No es sino en virtud de la intervención del Caballero de Gracia que, por su sacrificio, lograr salir de prisiones y encontrar de nuevo el lugar a su lado.

Las figuras alegóricas del Honor y el Cuidado acompañan al Hombre en los primeros compases de este auto sacramental. Intentan aconsejarle respecto a las decisiones que se le presentan en el camino, sin poderlo lograr. El Hombre, al igual que el demonio, peca de soberbia y se cree superior al resto. Por ello desoye los consejos de sus compañeros, atraído por los cantos de sirena de los vicios. No tardarán en abandonarle, dejándole a su suerte. El primero será el Cuidado, quien hasta el momento ha intentado con palabras suaves hacerle ver sus malas decisiones. Sin embargo, el Hombre le reprocha con desaires, lo que provoca que se marche de su lado, dejándole en compañía del Honor, quien acaba también por abandonarle. Cuando el Hombre cae en manos de Malicia y Lisonja, estas doblegan su Voluntad, quedándose solo. No podemos dejar de señalar lo simbólico de esta última separación, pues que el Honor abandone al Hombre no es sino un reflejo metafórico de su condena fatal, pues «tiene el mismo valor que la vida y de aquí que esta pueda ser quitada por cuestiones de honra» (Díez Borque 1976, 104). Un individuo deshonrado no 
tiene cabida en la sociedad española aurisecular, pues era considerado inferior al resto. Este concepto va ligado no solamente al de ser, sino también al religioso, concepto tan difícil de separar en la época. Como muestra de la importancia de este aspecto sociológico, el Honor no volverá a acompañar al Hombre hasta el final del auto sacramental. Una vez que sus pecados son perdonados, y ha vuelto a ser acogido en el seno de la Iglesia, se reúne con sus compañeros perdidos en el fin de fiesta.

La caída del hombre en el pecado determina el inicio de la Historia de la Salvación, dispuesta en el plan divino, la cual está prefigurada en la Biblia, con el anuncio de un Salvador en el Antiguo Testamento. Algunos profetas hacen referencia a este mesías con detalles concretos. Isaías lo describe con nombres que subrayan su unicidad: «Porque un niño nos es nacido, hijo nos es dado, y el principado sobre su hombro; y se llamará su nombre Admirable, Consejero, Dios Fuerte, Padre Eterno, Príncipe de Paz» (Is 9,6). Miqueas señala el lugar donde nacerá: «Pero tú, Belén Efrata, pequeña para estar entre las familias de Judá, de ti me saldrá el que será Señor en Israel; y sus salidas son desde el principio, desde los días de la eternidad» (Mi 5,2). Malaquías, por su parte, profetiza la figura de san Juan Bautista, como aquel que preparará el camino de este Salvador: «He aquí, yo envío mi mensajero, el cual preparará el camino delante de mí; y vendrá súbitamente a su templo el Señor a quien vosotros buscáis, y el ángel del pacto, a quien deseáis vosotros. He aquí viene, ha dicho Jehová de los ejércitos» (Mal 3,1). Así, en este auto sacramental, aparece este personaje antes que las naves del Caballero anunciando su llegada, adecuando las Sagradas Escrituras con la reflexión teológica que supone el concepto de la Historia de la Salvación. Finalmente Zacarías describe su entrada en Jerusalén: «Alégrate mucho, hija de Sion; da voces de júbilo, hija de Jerusalén; he aquí tu rey vendrá a ti, justo y salvador, humilde, y cabalgando sobre un asno, sobre un pollino hijo de asna» (Zac 9,9).

\section{LAS TROPAS DEL BIEN}

El Caballero de Gracia es, sin duda, la figura más interesante de este auto sacramental, pues bajo este título encontramos a Cristo, que encabeza su ejército para salvar al Hombre de las garras del demonio. La denominación de 'Caballero de Gracia' puede resultar curiosa, teniendo en cuenta que no encuentra ningún precedente documentado. Tan solo existen dos obras teatrales con este título, ambas de autor anónimo y manuscritas: el presente auto sacramental y otro del que ya hemos dado noticia, editado por Entrambasaguas. Algunos críticos, entre los que se encuentran Ven Serna (1967) o Alenda y Mira (2010) pretenden relacionarlo con la figura de Jacobo de Grattis, un caballero modenés que vino a España como secretario del nuncio apostólico de Gregorio XII y que, posteriormente, se estableció en Madrid. Adquirió gran fama tanto por la 
fortuna que adquirió como por los actos de generosidad con la Iglesia que llevó a cabo, cediendo terrenos y edificios para formar cofradías, iglesias y conventos. Falleció en 1619 a la edad de 102 años. Mesonero Romanos da noticia de su figura y su importancia en relación a la villa de Madrid:

Fue este ejemplar sacerdote natural de Módena, caballero de la Orden de Cristo, y murió en Madrid de 102 años en 1619; vivió en esta calle, a que dio nombre, y está enterrado en esta iglesia. Pónese esta noticia para que no se le confunda con el otro Jacobo Trezo, escultor y fundidor de Felipe II, pues la casualidad de vivir en Madrid a un mismo tiempo en calles inmediatas, a que dieron nombre (Jacome-Trezo), ha hecho que Dávila, Quintana y Ponz los hayan creído uno sólo $(1833,164-165)$.

Tal vez la generosidad y fama de este sacerdote pudiera haber influido a la hora de otorgar a Cristo este sobrenombre. Sin embargo, estaríamos moviéndonos en el terreno de la mera especulación al carecer de las pruebas necesarias para demostrarlo. Por otro lado, tenemos que tener en cuenta que la trama de este auto se plantea en torno al conflicto entre dos ejércitos. A lo largo del texto el Caballero dejar entrever que su objetivo es encabezar una gran cruzada contra la herejía, similar a las que bajo el mandato papal se llevaron a cabo entre los siglos XI y XV. Se proclamaría Cristo a sí mismo con este título porque su deber era redimir a la humanidad del pecado original y devolverle la Gracia que había perdido. Sería, por tanto, una posibilidad que el sobrenombre fuera escogido en relación a la historia que se pretendía contar y no tanto a la destacada figura del sacerdote mencionado.

En consonancia con el tópico del miles christi, Cristo toma el papel del general de los ejércitos del Bien que, embarcados en sus naves, se dirigen a presentar batalla contra Luzbel y sus seguidores. El mundo de la caballería aparece reflejado en todo momento en clave alegórica y simbólica, lo cual se aviene bien con el moralismo y la religiosidad de la época. Los elementos que le caracterizan son los propios de un caballero que encarna la santidad que reclama el alegorismo del tópico paulino: «En la popa el Caballero de Gracia, vestido de blanco, una gola, manto y bastón y una corona de laurel» (f. $12 \mathrm{v}^{\circ}$ ). El vestuario tiene como función situar al personaje como una figura de gran poder dentro de la jerarquía militar y eclesiástica, a través del valor del color blanco y de los laureles que coronan su sien. Como general, se encarga de dirigir sus tropas desde la popa de la nave principal, al tiempo que maneja su timón, en una clara referencia a la labor que desempeña el Papa desde la sede en Roma. La nave salvadora establece una relación directa con la nave de la Iglesia, que, a su vez, establece unos claros paralelismos con el modelo del Arca de Noé y la barca de Pedro, embarcaciones que simbolizan la salvación a través del favor divino. El ornato del que se recubren los elementos de escenografía y utilería, escasamente mencionados en las acotaciones, ayudan a reforzar la imagen positiva de Cristo y aquellos que le acompañan frente a los males que combaten: 
Sacan una trompeta y aparécese una nave. En la proa san Pedro, armado con una tiara como se ponen los pontífices [...] y un estandarte con las armas del santísimo sacramento que coja la popa. Y en la cabecera una cruz grande y toda la nave llena de gallardetes del santísimo sacramento (f. $12 \mathrm{v}^{\circ}$ )

Toquen una trompeta y aparézcase encima de la torre de Babel el Hombre en prisiones. El Caballero de Gracia en su atalaya arrimado a una cruz en un torreón. (f. $\left.13 v^{\circ}{ }^{\circ}\right)$

Baja el Caballero de Gracia con una pica hecha de modo que sirva de cruz y el Mundo (f. 16).

La información que nos proporcionan estas acotaciones es de gran interés simbólico. En primer lugar encontramos las referencias al estandarte, destacado elemento militar cuya función es representar las armas del ejército que lo porta y en torno al cual se agrupan las tropas. Cobra mayor simbolismo este elemento si atendemos al origen etimológico que le otorga Covarrubias en su Tesoro: $\sigma \tau \alpha v \rho o ́ s$, cruz, porque «desde el emperador Constantino es costumbre traer los emperadores la santa Cruz en sus banderas». El hecho que el estandarte esté adornado con las armas de la Eucaristía pone mayor relieve en la lucha contra el luteranismo, ya que se defiende el sentido católico de la transustanciación frente a la consustanciación. La tiara, por su parte, simboliza el poder de las llaves y alude claramente a la ortodoxia católica por el concepto de Iglesia jerárquica defendido que emana del poder de las llaves conferido en Mateo 16,18-19:

Y yo también te digo, que tú eres Pedro, y sobre esta roca edificaré mi iglesia; y las puertas del Hades no prevalecerán contra ella. Y a ti te daré las llaves del reino de los cielos; y todo lo que atares en la tierra será atado en los cielos; y todo lo que desatares en la tierra será desatado en los cielos.

Contrasta con el concepto luterano, y protestante en general, de una Iglesia invisible, únicamente percibida por Dios. Por último, la torre de Babel es un evidente símbolo bíblico que refiere a la confusión, concretándose en el texto en la teológica que sufren los protestantes, los cuales son incapaces de ver la $\mathrm{Fe}$ verdadera.

Regidos por el código de la caballería, se decide que el conflicto entre ambas fuerzas se resuelva mediante un combate mano a mano entre dos campeones. Del bando del Bien se presenta la Fe, quien llega a ser una extensión del propio Caballero, pues es quien sustenta el pensamiento cristiano y la religión. Vence a su contraria, Malicia, que se presenta en nombre de Luzbel, precisamente porque es esta la virtud que sustenta todo el sistema de creencias. Cuando, aparentemente, la batalla ha finalizado, ocurre algo imprevisto. Amor, que ha salido con el Hombre de las prisiones de Luzbel, atraviesa con una lanza el cuerpo del Caballero. Un aparente acto de traición que no es sino una nueva alegoría simbólica de la Redención de Cristo, quien se entrega a sí mismo para salvar al Hombre de sus pecados. Para terminar de completar la ima- 
gen, Amor acerca el cuerpo alanceado a la cruz, volviendo a traer simbólicamente sobre las tablas el episodio de la crucifixión de Cristo. Ante esta visión, a Luzbel y sus seguidores no les queda más opción que huir, aunque prometen su venganza:

Luzbel ¡Huye Malicia! ¡Herejía!

Malicia ¡Ah, Luzbel! Pues, ¿no escarmientas?

¿No lloras esta desdicha?

Luzbel Yo procuraré vengarme (f. 16v. ${ }^{\circ}$ ).

El Caballero, entonces, establece la eucaristía, en la que se llevará a cabo la transustanciación del pan y el vino, en recuerdo de su sacrificio:

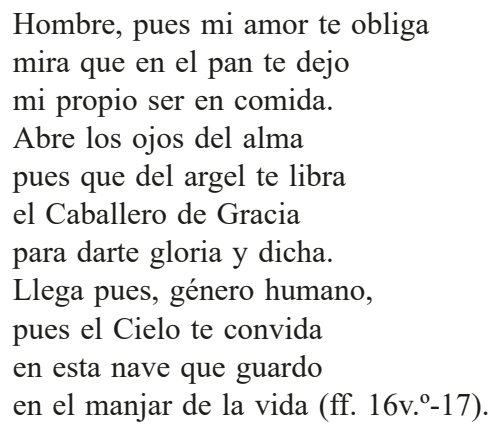

Todos los parlamentos que hacen los personajes del ejército del Bien van dirigidos a luchar contra las herejías del luteranismo. Así, se mencionan en varias ocasiones a los siete sacramentos, frente a los tres que Lutero promulgaba; la transustanciación frente a la consustanciación; por no señalar las numerosas menciones a Lutero, Arrio y Calvino como herejes y compañeros del demonio.

El papel de la Fe se complementa con el de san Pedro. Si esta representa la virtud teologal, san Pedro encarna al primado, instituido gracias al otorgamiento del poder de las llaves a él y a sus sucesores. Goza de la estima del de Gracia y aparece caracterizado con una tiara, como pontífice. Su aparición en escena se produce sobre la proa de la nave principal, en contraposición a su general que se encuentra en la popa. Se sitúa, por tanto, como cabeza visible de la nave de la Iglesia, vigilante frente a los males que la acechan, formando su vanguardia, presto para avisar al resto de las tropas de los peligros que pudieran amenazarla. Se refuerza así el carácter de 'depósito de la fe' que en la creencia católica corresponde al papado. De todos los diálogos que aparecen es el único que tiene voz. En todo momento se muestra solicito y dispuesto con el Caballero, actuando airado ante las provocaciones de Luzbel y sus seguidores. 
San Juan Bautista, por su parte, cumple con su papel de predicador, al igual que en las Sagradas Escrituras, anunciando la llegada de Dios hecho hombre, de ahí su tradicional consideración como el Precursor de Cristo. Al mismo tiempo, pone en aviso al espectador acerca de lo que va a presenciar. A partir de su intervención cambia el tono de la obra, pasando de la historia de un individuo a una mayor dimensión: Luzbel y sus ejércitos se pertrechan en su fortaleza al tiempo que las naves del Caballero toman la orilla. El parlamento final del Bautista antes de la batalla expone con claridad lo que ha pasado y lo que pasará: el alma del Hombre está condenada, pero será salvada por la intervención de Cristo:

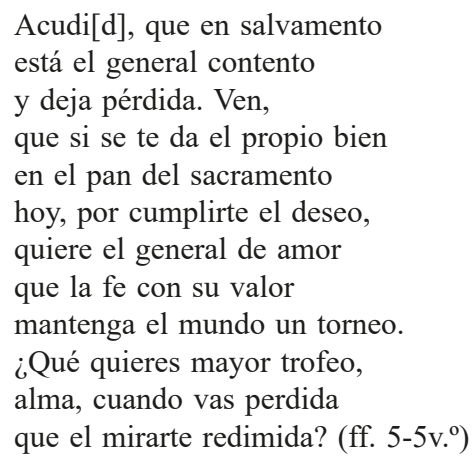

Estos son los principales personajes que forman parte del ejército del Bien comandado por el Caballero de Gracia. Sin embargo, no son los únicos. Personajes como santo Domingo, san Francisco de Asís, santo Tomás, san Agustín, san Pablo o san Juan Evangelista también engrosan sus filas, llegando a participar incluso de manera representativa en la acción. La intervención de los santos medievales, santo Domingo o san Francisco, también intensifica la ortodoxia de la obra frente a la consideración que los protestantes tenían de su heroicidad moral. Del mismo, la presencia de santo Tomás, y por ende de la doctrina que este representa, supone la reafirmación tridentina de la Escolástica renovada, tan denostada por Lutero, a partir del Concilio de Trento. Se trata de breves intervenciones, más apoyadas en la representación visual que en el diálogo, cuya función es reforzar la idea de un poderoso ejército, al tiempo que se apoya en el imaginario colectivo del público, que reconoce a estas figuras a través de las representaciones pictóricas o escultóricas de las iglesias o sus menciones en sermones y textos sagrados. No obstante, el otro bando presenta también personajes memorables y característicos.

\section{LA SOLDADESCA DEL MAL}

Luzbel es un personaje dramático con un sutil punto cómico en el que predomina la ironía por la situación en la que se encuentra. Es el máximo re- 
presentante del Mal y el general de sus ejércitos, en contraposición a la figura del Caballero de Gracia. Este demonio no es astuto, no pone trampas al Hombre, no propone ni urde engaños para llevarlo al pecado ni siquiera cuando está ante su presencia lo manipula de modo alguno para que haga su voluntad. Cuando aparecen las naves del ejército del Bien no se enfrenta a ellos personalmente, sino que deja que sea su campeón quien se enfrente en combate singular. Con ardides y artimañas deja que sean otros quienes luchen.

No obstante, su destino está predeterminado en todas las obras de este género y este auto no es una excepción. Por muchos empeños, al final acabará todo en un fracaso para el Mal y un nuevo triunfo para el Bien. Todo ello se debe a que, desde su osada rebelión contra Dios, no puede hacer otra cosa que reiterar su intención primera en cada una de las oportunidades que se le presentan, para ver cómo, inevitablemente, todo vuelve a derrumbarse ante el triunfo de los ejércitos de Cristo. El propio Luzbel narra en largos parlamentos fragmentos del relato bíblico donde ilustra sus diversas derrotas ante Dios, algo que no es más que un preludio de cómo acabará la obra. La historia volverá a repetirse una vez más.

La aparición del demonio en el auto sacramental responde a una clara intención: ofrecer un continuado y exhaustivo panorama del enfrentamiento del Bien contra el Mal bajo los conceptos de la teología católica. Por tanto, para el espectador, la encarnación suprema de este Mal debe ser representada clara y distintivamente. No obstante, esta no debe limitarse a un personaje, pues los vicios y pecados que aparecen en escena se encargan de completar todos los posibles aspectos del mismo, de una manera más particular para hacer caer al Hombre en el pecado. Si en el bando del Bien la soldadesca la formaban santos y mártires, el Mal se compone por alegorías como Envidia, Malicia o Lisonja, entre otros, que se encargan de conducir al Hombre hasta su perdición, personificada en la figura de Luzbel, que, sin actuar de una manera directa en ningún caso, recibe en sus manos el premio.

Pero, sin lugar a dudas, hay un aspecto de este personaje que lo diferencia de otras encarnaciones del Demonio. Luzbel no busca vengarse del Creador, ni recuperar el lugar que perdió junto a las huestes celestiales. No va en busca de una batalla o una guerra, ni frustrar planes divinos. Al contrario, son las tropas del Bien las que llegan a sus puertas, dispuestas a salvar al Hombre que ha caído en las garras de sus tropas. Cumple, por tanto, con su papel de intentar alejar al Hombre de Dios, tentándolo con promesas y vicios que le aparecen en su camino. Debido a esta posición en que se coloca, más parece un predicador del Evangelio que predica largos parlamentos extraídos de manera directa de las Escrituras que un ser demoniaco deseoso de enfrentarse a los ejércitos celestiales para recuperar el lugar del que lo expulsaron. Con esto, el autor seguramente quiso establecer un paralelismo con la situación político-religiosa del momento. El Bien contra el Mal; el catolicismo frente al protestantismo; dos posturas de un mismo camino que, mediante la palabra, pretenden engrosar 
sus respectivas filas. Sin embargo, solo una es la verdadera y será la encargada de reconducir y salvar a aquellos hombres que tomen el camino equivocado.

Como hemos mencionado, pese a no buscar batalla, el Hombre la encuentra a las puertas de sus dominios, cuando el ejército del Bien aparece armado. En ese momento, el demonio sufre una transformación, tomando las armas y convirtiéndose en general de sus ejércitos y dispone a sus tropas con ingenio táctico para contrarrestar la amenaza:

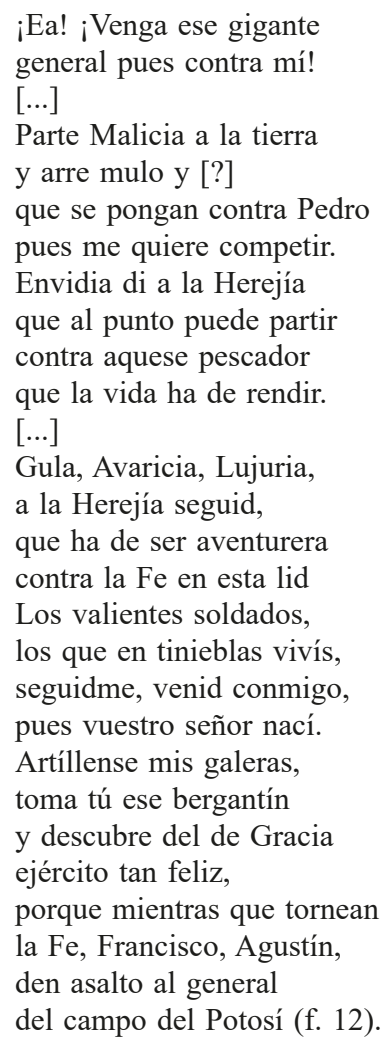

Pese a que conocemos el final del auto, el triunfo de la Luz sobre la Oscuridad, no deja de sorprendernos una pequeña variación que deja en suspenso al auditorio en los minutos finales. Como está previsto, la Fe supera a la Malicia en combate singular y se alza vencedora. Pero, a continuación, entra en escena el Hombre y el Amor, quien lancea al Caballero de Gracia, matándolo en el acto:

Caballero ¡Ay Amor! ¡Di de rodillas!

Luzbel Enristró Amor y la lanza

dividida en mil astillas 
derribó el de Gracia en tierra (f. 16).

De golpe, el desenlace no es el esperado. El general del Bien ha sido traicionado, supuestamente, por alguien de su propio bando. No obstante, tiene su explicación lógica: sin la muerte de Cristo por amor al hombre no puede haber una salvación verdadera del alma. La lanza clavándose en su costado remite a Juan 19:34-35: «pero uno de los soldados le traspasó el costado con una lanza, $\mathrm{y}$ al momento salió sangre y agua. $\mathrm{Y}$ el que lo ha visto ha dado testimonio, y su testimonio es verdadero; y él sabe que dice la verdad, para que vosotros también creáis». Para acabar de reforzar la imagen presentada sobre las tablas, el Caballero acaba colgado de la Cruz en un claro símil figurativo:

Malicia ¡Otra lanza tomó Amor!

Luzbel ¡Qué valor!

Malicia ¿Qué valentía!

Luzbel ¡Arrimádole a la cruz!

Aparece el Mundo y dice. Y en lo alto Dios y el Hombre a sus pies.

Mundo ¡Libertad!

Luzbel ¡Qué triste día!

Venció Dios pues que con voces

la libertad apellidan.

Hombre Bien sé que sois Redentor (f. 16 v. ${ }^{\circ}$ ).

Santo Tomás explica que en el momento en el que surge del cuerpo de Cristo la sangre y el agua nacieron los sacramentos, que, a diferencia de la opinión de Lutero sí confieren la gracia. Esto lo expone en su obra Summa Teológica en varios de sus apartados: «[los sacramentos] tuvieron fuerza en la sangre y agua, que de el lado de Cristo salió, tras el golpe de la lanza con que, depués de muerto, le rompieron el pecho» (Jiménez Patón 2014, 135-136). Es doctrina tradicional de la Iglesia, pues la Gracia se pierde en el Hombre por el pecado original, culpa de Adán. La redención supone la liberación del primer pecado y gracias a ello, la restitución de la Gracia, de ahí el apelativo de este Caballero. De no ser por este sacrificio voluntario, el Hombre no podría escapar por completo de las prisiones de Luzbel y entregarse a la verdadera Fe. Cuando el demonio es consciente de la derrota total de su ejército no le queda más remedio que emprender la huida, reuniendo a sus tropas, a la espera de una nueva oportunidad para vengarse:

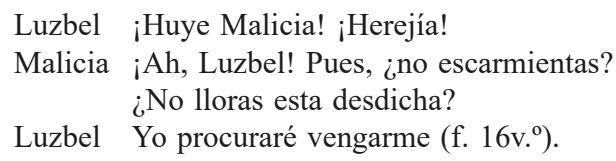

Se reflejan así dos aspectos: por un lado, la naturaleza cobarde y huidiza del demonio, quien nunca podrá ganar frente a los seguidores de Cristo. Por 
otro, la eterna lucha entre la Luz y la Oscuridad, entre Dios y el Demonio, que durará hasta el fin de los tiempos, cuando el Bien triunfe definitivamente, tal como aparece relatado en Apocalipsis.

Luzbel cuenta con distintos subalternos que lo acompañan y preceden. Son los que cautivan al Hombre cuando este se separa de su bando y lo llevan por el mal camino hasta la guarida de su señor.

Cuando Malicia se presenta ante el Hombre por primera vez lo hace disfrazada de Ignorancia. Bajo su influencia tropieza en vicios, como el juego o la lujuria, ignorando los consejos de Honor y Cuidado, quienes lo acompañan. Ayudada por Lisonja, quiebra a la Voluntad y lo conduce a las puertas de Luzbel. El texto presenta una clara dificultad a la hora de comprender el mecanismo de enredo del que hace uso este personaje, debido a la escasez de acotaciones explicativas. El juego del disfraz puede resultar confuso, pues no se desarrolla de manera explícita el intercambio de personajes y tampoco se hace uso de ninguna acotación aclaratoria. Sin embargo, no tarda en revelar su verdadera naturaleza cuando el Hombre ha sido abandonado por sus compañeros. La Malicia se presenta en el auto con un juego pícaro y resoluto. Responde a las palabras de san Juan Bautista cuando se encuentra con él con descaro:

S. Juan ¡La verdad publicaré!

Malicia Amargan ya las verdades (f. 5).

Cuando es elegida como campeona del demonio para luchar en duelo, provoca a su contrario con cuestiones propias de herejes y ateos que pretenden socavar la Fe:

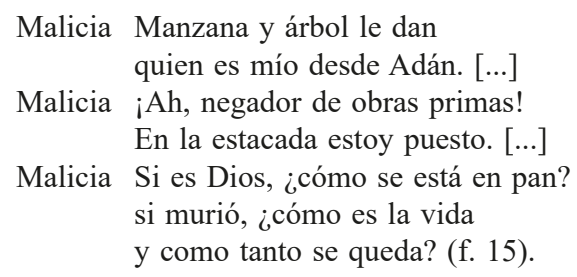

En estas intervenciones encontramos toda una serie de referencias posibles. En primer lugar, al concepto teológico de la 'Historia de la Salvación', que tiene como pilares fundamentales las figuras de Adán y Cristo. La teología sostiene que el hombre perdió su estado edénico, y consecuentemente la inmortalidad, tras desobedecer el mandato divino al rendirse a la tentación de la serpiente (Génesis 3). Su caída en el pecado justifica el concepto teológico de la 'Historia de la Salvación' por el cual Dios traza un proyecto de salvación que se va manifestando a lo largo del Antiguo y del Nuevo Testamento. Su fin fundamental es la redención del hombre que comporta el sacrificio de Jesucristo. En el segundo fragmento encontramos uno de los conceptos centrales durante el Concilio de 
Trento: la importancia de las obras, junto a la fe, para la justificación. Lutero, por su parte, defendía la fe como único medio a través del cual ascender a la salvación. El último fragmento, por su parte, hace referencia a la transustanciación y, también, a la renovación del sacrificio de Cristo, en este caso incruento, en la celebración de la misa. De ahí la defensa del carácter sacrificial de la misa frente a los protestantes. Malicia pregunta retóricamente acerca de estos conceptos en un tono escéptico y burlón, apropiándose de las ideas contrarreformistas, las cuales rechazan la transustanciación aunque sí acepten la consustanciación. Para Lutero solo una vez se produjo el sacrificio en la Cruz y es irrepetible. Sin embargo, para la creencia católica, este se reproduce cada vez que el sacerdote oficia la consagración durante la misa de forma incruenta. No obstante, pese a todas estas provocaciones que tienen como objetivo poner en tela de juicio la fe católica, acaba siendo vencida por su adversario y, tras ser el Caballero alanceado, huye junto a Luzbel y la Herejía.

La Envidia es la representación externa de ese pecado que configura la esencia misma del demonio, junto a la soberbia. Aparece en escena cuando las naves del Caballero de Gracia aparecen en la lejanía y narra para su señor, y en extensión para el público, la historia del mismo, situándolo como su contraparte. El tono es rabioso y rezuma envidia por los logros que su contrario ha conseguido, instando a su señor a prepararse contra la amenaza que se les aproxima.

La Herejía, por su parte, representa al gran conjunto de creencias controvertidas que entran en conflicto con el dogma católico. Pese a que el más reconocido en la época o el que más importancia tuvo fue el luteranismo, este personaje alegórico recoge también otros como el arrianismo o el calvinismo. Aparece siempre acompañada por el representante de alguna de estas herejías y marcha al lado de la Malicia cuando se enfrenta a la Fe. Se muestra, pues, que tanto las herejías antiguas como contemporáneas, han combatido la ortodoxia que encarna la Iglesia.

Entre los dos bandos se sitúan tres personajes que representan entidades abstractas de carácter neutro que deben ser tenidos en cuenta en este análisis. Estos son el Tiempo, el Mundo y la Muerte. No podemos asignarlos exactamente a uno de los dos bandos, pues no desempeñan ninguna función en ellos ni buscan beneficiarse de la victoria de uno u otro. El Tiempo aparece ante el Hombre en un intento de avisarle de la situación en la que se encuentra. No obstante, su consejo será ignorado. El Mundo es como el Hombre, una representación general de todo el género humano. Por ese mismo motivo se encuentra prisionero con él y no será hasta el sacrificio del Caballero cuando sea liberado gritando «iLibertad!» (f. 16v. ${ }^{\circ}$ ). Este deseo expresado no es solo propio, como personaje, sino como conjunto global que se libera del demonio y sus males, abrazando nuevamente la fe verdadera. La Muerte se presenta ante el Hombre como la advertencia última. Los pecados que ha ido cometiendo por 
el camino han provocado que se le aparezca cuando se encuentra encarcelado y le informa sobre su destino:

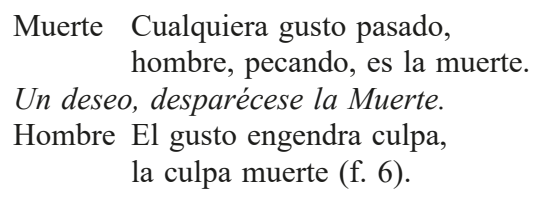

Estas palabras son una clara referencia a Santiago 1:15: «El pecado consumado engendra muerte». En el Génesis hace aparición por primera vez el concepto de la muerte para el hombre y del tiempo. Hasta el momento de la expulsión era eterno, pues en el Paraíso no existía la muerte. Pero cuando Dios lo expulsa, se vuelve mortal y padece los dolores y sufrimientos del mundo.

\section{SERMÓN SOBRE LAS TABLAS}

La influencia del teatro en la predicación es un hecho irrefutable que comienza a tomar fuerzas a partir del Concilio de Trento, partiendo sin duda de los decretos que promovieron las reformas arquitectónicas de los templos, haciéndolos más accesibles y abiertos para que los fieles pudieran observar de manera directa el misterio de la eucaristía. El cardenal san Carlos Borromeo publicó en 1577 un tratado de arquitectura, Instructionum Fabricae et Supellectillis Eclesiasticae, en el que proponía una serie de cambios en la estructura de las iglesias catedrales para hacerlas más abiertas, siempre con un propósito de accesibilidad. De la espectacularidad del teatro se nutren los altares para atraer al público y difundir la palabra de Dios, pero no solamente en el púlpito, sino también a través de los autos sacramentales. Por ello los elementos parateatrales tales como la escenografía, la música o el vestuario, cobran gran importancia. Estos ayudan a dotar la obra de gran espectacularidad que afectaba al espectador, despertando su admiración y fijando la doctrina impartida. La escenografía, por ejemplo, desempeña una función de impacto visual, pues contribuye a la ubicación espacial y, al mismo tiempo, a la visualización simbólica de los motivos tratados. Además, podía darse el caso de que el escenario contara con trampillas o tramoyas que ayudarían a elevar piezas para dar mayor espectacularidad. Así lo podemos ver en palabras del padre Pedro de Calatayud:

Cogidos de repente los gritos y amenazas divinas, les llenan de pavor y temor, les penetran, hieren y suelen darse a discrección, y el crucifixo, luces, campanilla, la noche, el silencio de los que van entrando, y siguiendo, compunge, penetra, y hiere juntamente con las voces a varios que salen a las puertas, balcones y ventanas... Hacen que imaginen figuras horribles, y aun a los mismos espíritus malos, inmutando la imaginación, e infundiendo pavor y miedo en el apetito. Unas veces imaginan ya dormidos, ya despiertos, que oyen la campanilla con que les invoca- 
mos por las calles, como nos lo han asegurado varios; otros, que oyeron y vieron a los misioneros predicar de noche, hasta afirmar que con los ojos del cuerpo los vieron (Gelabertó 2005, 77).

Desgraciadamente la falta de acotaciones de este texto nos priva de la posibilidad de conocer en más detalle los escenarios y recursos que el despliegue de esta obra necesitaba. En contadas ocasiones se mencionan aspectos concretos y determinados. Entre estas, destaca la explicación pormenorizada del aspecto de la nave en la que aparece el Caballero de Gracia, pues explica cómo debe estar decorada y con qué elementos, a fin de formar una imagen emblemática reconocible para el espectador de la obra:

Sacan una trompeta y aparécese una nave. En la proa san Pedro, armado con una tiara como se ponen los pontífices [...] y un estandarte con las armas del santísimo sacramento que coja la popa. Y en la cabecera una cruz grande y toda la nave llena de gallardetes del santísimo sacramento. San Pablo y san Juan evangelista y, sentado junto al caballero, la Esposa muy bizarra y la Fe (f. $12 v^{\circ}{ }^{\circ}$ ).

Esta falta de acotaciones también perjudica la labor interpretativa del texto, al carecer de cualquier indicador, ya sea de carácter espacial, musical o referente al vestuario. Al comenzar la obra no sabemos dónde se encuentra el Hombre. A medida que avanza la trama tampoco podemos reconocer qué elementos conforman su entorno. Cuando llega frente las puertas de Luzbel solo podemos conjeturar que se encuentra ante una fortaleza. Seguramente el despliegue escenográfico tenía que impresionar visualmente para mostrar el lugar en el que residía un demonio de tal categoría o las naves de la Iglesia. Apariciones como las de la Torre de Babel o los torreones con almenas desde los que hablan Luzbel y el Caballero de Gracia, precisarían de mecanismos que permitieran elevarlas y ocultarlas, ya que debían surgir del suelo o tras otras estructuras, creando un espectáculo maravilloso ante los ojos de los espectadores.

El vestuario, junto a la escenografía, ayuda a dar mayor significado simbólico y visual a los personajes, además de ser un recurso que permite la espectacularidad debido al colorido y el recargamiento ornamental. El contraste es claramente visible entre los tipos de personajes, con lo que también ayuda al espectador a mostrar su inclinación hacia uno de los bandos. En los autos sacramentales se distinguen dos tipos de vestuario: el mimético y el alegórico. El primero pretende una imitación, más o menos realística, de la figura de la que procede, incluyendo también los personajes sobrenaturales o abstractos. En estos casos la mimesis se conseguía a través de la emblemática o de la pintura codificada, las cuales remiten a las representaciones que los espectadores estaban acostumbrados a contemplar en los templos. El alegorismo, por su parte, se fundamenta en mecanismos expresivos que codifican cada pieza del vestuario en relación con la doctrina católica y el contexto de la obra. Sin embargo, 
nuevamente, la falta de acotaciones a este respecto hace que no podamos ofrecer un análisis pormenorizado de estos elementos. Tan solo del Caballero de Gracia se ofrece una descripción pormenorizada del atuendo que viste: «En la popa el Caballero de Gracia, vestido de blanco, una gola, manto y bastón y una corona de laurel» (f. $12 \mathrm{v}^{\circ}{ }^{\circ}$ ). Se puede recuperar también el vestuario que porta el Hombre en la primera parte del auto sacramental a raíz de la descripción que él mismo hace:

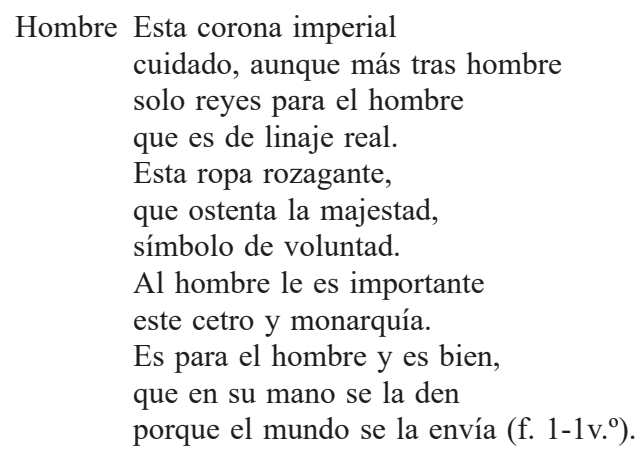

Otro personaje que debería tener una acotación respecto a sus vestiduras es la Malicia, la cual aparece disfrazada ante el Hombre. El ocultamiento de su identidad pudiera conseguirse con una simple capa o, al hacerse pasar por la Ignorancia, vistiendo sus atributos alegóricos para después reemplazarlos por los propios. Sin embargo, no podemos conocer estos mecanismos, pues las acotaciones no las reflejan.

La liturgia y la defensa del dogma católico son el eje principal en torno al que se estructura el auto. Debido a ello las referencias bíblicas son abundantes, llegando a reproducir de forma libre pasajes completos, como por ejemplo el Génesis. De igual modo, aparecen muchos comentarios dirigidos contra la Reforma luterana y sus seguidores.

En este aspecto no presenta ninguna innovación frente a los autos sacramentales de la época, los cuales tienen como fin representar sobre las tablas el misterio de la Eucaristía, la difusión del dogma católico y el ataque contra cualquier forma de herejía.

Los discursos del Caballero se asemejan a sermones, referenciados todos a su vida tal como viene narrada en el Nuevo Testamento. Ya así definía Calderón el concepto de auto sacramental: «sermones / puestos en verso, en idea / representable cuestiones / de la sacra teología» $(1677,293)$. La vida de Cristo se presenta como una cruzada a Tierra Santa para liberar Jerusalén, acompañado de sus doce apóstoles. Es el general del ejército, por lo que mantiene una actitud reservada y propone a la Fe para luchar en duelo singular contra un elegido del ejército del Mal. A diferencia de Luzbel, sus parlamentos son menos extensos, pero con una mayor carga simbólica y religiosa, sin vanagloriarse de 
sus victorias. El resto de personajes del ejercito del Bien se encargan de terminar de construir la trama y explicar los misterios que la envuelven. La Fe, por ejemplo, es la encargada de explicar los fenómenos que solo pueden ser comprensibles a través de ella, como la transustanciación:

Y aunque solo el pan se ve en el uno y trino estáis.

Hoc es[t] corpus me enseñáis.

Yo lo creo en buena fe,

co se ve que sois franco (f. $13 v^{\circ}$ ).

O el misterio de la Trinidad:

Es su ser persona trina, su inmensidad singular, su ser de sí se deriva, hecho sin principio o fin $\mathrm{y}$ en fin una esencia trina. Enciérrase en mí el ser Dios

y en mi se queda su herida porque es Dios que hacerlo pudo y su incrédula porfía.

Niegas lo que afirmo yo, que es tu principio la envidia, naciendo yo del que es Dios y tú de envidia y malicia (f. $15 v^{\circ}{ }^{\circ}$.

Respecto al léxico empleado en la obra predominan los campos léxicos referentes al mundo náutico y militar. Con estos se hace un continuo juego de dobles significantes, mezclando el propio con el religioso. De este modo, las naves hacen referencia tanto a las embarcaciones en las que el ejército de Cristo cruza los mares como al propio templo. El Hombre milita como soldado en un ejército real, pero también en el del Caballero, cumpliendo, por tanto, con el tópico del miles christi paulino. Este juego es continuo a lo largo de toda la obra, a fin de transmitir una serie de ideas religiosas a través de otros conceptos más cercanos al espectador.

\section{CONCLUSIONES}

Hasta la fecha este auto sacramental, como hemos podido comprobar, no ha sido objeto de la atención de la crítica, pese a haber sido citado en varias ocasiones a lo largo del tiempo. Citas que, por otra parte, se ha demostrado que han sido hechas sin haber manejado previamente el texto. Se trata de una obra dramática con una gran carga antiluterana que cumple con las expecta- 
tivas culturales de la época y participa en su controversia religiosa. Al presentar el erasmismo, tenido por prólogo de la Reforma aunque sin llegar a la herejía, vinculado a las fuerzas del Mal refuerza la postura de la Iglesia católica en su contra, al tiempo que asienta el mensaje en el imaginario colectivo. La estructura de la trama se organiza en torno a dos tópicos recurrentes: la eterna batalla del Bien contra el Mal, que encontramos mencionado de manera recurrente en las Sagradas Escrituras, así como el miles christi paulino que asentó no solo un modelo literario sino también de pensamiento. El desarrollo del tema se refuerza mediante la recreación de pasajes testamentarios, en los que se alude a la redención mediante paradojas con las que pretende hacer accesible al lector el misterio que encierra la figura de Cristo: morir para vivir $\mathrm{y}$, de este modo, salvar al género humano. Los personajes, a diferencia de los que aparecen en otros autos sacramentales, no se limitan a ser arquetipos o simples máscaras sobre las que colgar las vestiduras. Presentan rasgos propios que los diferencian, tomados de manera directa de la Biblia, convirtiendo así sus intervenciones en sermón vivo sobre las tablas. La predicación toma la escena creando un espectáculo visual a través del cual fijar en la retina y en la mente del espectador tanto el contenido de las escrituras como el discurso teológico católico, en una clara pugna con la ideología contrarreformista. El teatro, pues, se convierte en el escenario de una batalla entre las fuerzas del Bien y del Mal cuyo último objeto es la salvación del Hombre, para ejemplo y fin del espectador.

\section{FUENTES}

Alenda y Mira, Jenaro. 2010. Catálogo de autos sacramentales, historiales y alegóricos, Alicante: Biblioteca Virtual Miguel de Cervantes; Madrid: Biblioteca Nacional. http://www. cervantesvirtual.com/obra/catalogo-de-autos-sacramentales-historiales-y-alegoricos/

Anónimo. El caballero de Gracia: auto sacramental. Emp.: ¿Dónde me llevas asida? (h. 1)... Fin.: que estos borrones escriba (h. 17v), [Manuscrito], sig. 16568, Madrid: Biblioteca Nacional.

Barrera, Cayetano. 1860. Catálogo bibliográfico y biográfico del teatro antiguo español desde sus orígenes hasta mediados del s. XVIII. Madrid: Ribadeneyra. http://www. cervantesvirtual.com/obra/catalogo-bibliografico-y-biografico-del-teatro-antiguoespanol-desde-sus-origenes-hasta-mediados-del-siglo-xviii--0/

Borromeo, Carlo. 1577. Instructionum Fabricae et Supellectilis Ecclesiasticae. Milán.

Calderón de la Barca, Pedro. 1677. Autos sacramentales alegóricos e historiales [Manuscrito], Madrid.

Covarrubias, Sebastián. 2006. Tesoro de la lengua castellana o española. Ed. Ignacio Arellano y Rafael Zafra. Madrid - Frankfurt: Iberoamericana - Vervuert.

Mesonero Romanos, Ramón. 2008. Manual de Madrid. Descripción de la Corte y de la Villa. Madrid: Imprenta de M. de Burgos, 1833. Edición digital de la Biblioteca Virtual Miguel de Cervantes, 2008. http://www.cervantesvirtual.com/obra/manual-de-madriddescripcion-de-la-corte-y-de-la-villa--0/ 
Remón, Alonso. 1620. Vida ejemplar y muerte del Caballero de Gracia, Madrid: Diego Flamenco.

\section{BIBLIOGRAFÍA CITADA}

Arellano, Ignacio. 2001. Estructuras dramáticas y alegóricas en los autos de Calderón. Kassel: Reichenberger.

Clavería, Carlos. 1950. «Le chevalier délibéré» de Olivier de la Marche y sus versiones españolas del siglo XVI. Zaragoza: Institución Fernando el Católico, CSIC.

Díez Borque, José María. 1976. Sociología de la comedia española del siglo XVII. Madrid: Cátedra.

Entrambasaguas, Joaquín. 1952. El caballero de Gracia. Auto sacramental de autor desconocido. Barcelona: Subirana.

Fernández, Xavier. 1991. Las comedias de Tirso de Molina. Ensayos de crítica textual. Vol. I-III. Kassel: Reichenberger.

Gelabertó, Martí. 2005. La palabra del predicador: contrarreforma y superstición en Cataluña (siglos XVII-XVIII). Lleida: Milenio.

Herrán Alonso, Emma. 2005. «La configuración del tópico del "miles christi” entre la Edad Media y el Renacimiento». En Actes del X Congrés Internacional de l'Associació Hispánica de Literatura Medieval, coord. Josep Lluís Martos Sánchez, Josep Miquel Manzanaro i Blasco y Rafael Alemany Ferrer, vol. 2, 879-893. Alicante: Universidad de Alicante.

Jiménez Patón, Bartolomé. 2014. El virtuoso discreto, primera y segunda parte. Ed. Jaume Garau y María del Carmen Bosch. Madrid - Frankfurt: Iberoamericana -Vervuert.

Morley, S. Griswold. 1914. «El uso de las combinaciones métricas en las comedias de Tirso de Molina». Bulletin Hispanique 16 (2): 177-208.

Rodríguez-Puértolas, Julio. 1970. «La transposición de la realidad en los autos sacramentales de Lope de Vega». Bulletin Hispanique 72 (1-2): 96-112.

Serna, Ven. 1967. «Observaciones sobre el arte de Alonso Remón, dramaturgo lopista». En Actas del Segundo Congreso Internacional de Hispanistas, ed. Jaime Sánchez Romeralo y Norbert Poulussen, 591-597. Nimega: Instituto Español de la Universidad de Nimgea.

Fecha de recepción: 22 de enero de 2018.

Fecha de aceptación: 19 de abril de 2018. 